\title{
Critical thinking of student nurses during clinical accompaniment
}

\author{
BY Uys, MCur (Advanced Nursing Education) \\ Lecturer: Nursing Sciences Department of Nursing Science, University of Pretoria
}

SM Meyer, PhD (Computer Integrated Education)

Lecturer: Nursing Education and Advanced Nursing Dynamics Programme

Manager: Flexi Learning Department of Nursing Science University of Pretoria

\section{Keywords:}

Clinical facilitator, Critical thinking, Facilitation

\section{Correspondence address:}

Dr SM Meyer

Department of Nursing

School of Health Care Science

Faculty of Health Sciences

University of Pretoria

PO Box 667

Pretoria

0001

Tel: 0123542125

Fax: 0123541490

E-mail: salome.meyer@up.ac.za

\section{Abstract: Curationis 28(3): 11-19}

The purpose of this study was to investigate the methods of clinical accompaniment used by clinical facilitators in practice. The findings of the study also reflected facilitators' perceptions regarding critical thinking and the facilitation thereof.

A quantitative research design was used. A literature study was conducted to identify the methods of accompaniment that facilitate critical thinking. Data was collected by means of a questionnaire developed for that purpose. Making a content-related validity judgment, and involving seven clinical facilitators in an academic institution, ensured the validity of the questionnaire.

The results of the study indicated that various clinical methods of accompaniment were used. To a large extent, these methods correlated with those discussed in the literature review. The researcher further concluded that the concepts 'critical thinking' and 'facilitation' were not interpreted correctly by the respondents, and would therefore not be implemented in a proper manner in nursing practice. Furthermore, it seemed evident that tutor-driven learning realised more often than student-driven learning. In this regard, the requirement of outcomes-based education was not satisfied. The researcher is therefore of the opinion that a practical programme for the development of critical thinking skills during clinical accompaniment must be developed within the framework of outcomes-based education.

\section{Opsomming}

Die doel van hierdie studie was om die metodes van kliniese begeleiding wat deur kliniese fasiliteerders in die praktyk gebruik word, te ondersoek. Die bevindinge van die studie reflekteer ook fasiliteerders se persepsies aangaande kritiese denke en die fasilitering daarvan. " $n$ Kwantitatiewe navorsingsontwerp is gebruik. ' $n$ Literatuurstudie is uitgevoer om die metodes van begeleiding wat kritiese denke fasiliteer, te identifiseer. Data is deur middel van ' $n$ vraelys wat vir dié doel ontwerp is, ingesamel. Die geldigheid van die vraelys is verseker deur die bepaling van ' $n$ inhoudverwante geldigheidsoordeel deur sewe kliniese fasiliteerders van ' $n$ akademiese instelling.

Die resultate van die studie het aangetoon dat verskeie kliniese begeleidingsmetodes gebruik is. Hierdie metodes het in 'n groot mate ooreengestem met dié wat in die literatuurstudie bespreek is. Die navorser het voorts tot die slotsom gekom dat die konsepte "kritiese denke" en "fasilitering" nie korrek deur die respondente geïnterpreteer is en dus nie op ' $n$ behoorlike wyse in die verpleegpraktyk geïmplementeer sal word nie. Dit het voorts duidelik geblyk dat dosent-gedrewe leer meer dikwels realiseer as student-gedrewe leer. In hierdie opsig is daar dus nie aan dié vereiste van uitkomsgebaseerde onderrig voldoen nie.

Die navorser is dus van mening dat 'n praktiese program binne die raamwerk van uitkomsgebaseerde onderrig vir die ontwikkeling van kritiese denkvaardighede gedurende die kliniese begeleiding van studente ontwikkel moet word. 


\section{Introduction and problem statement}

The most important purpose of nursing education is to provide students with learning opportunities that will enable them to develop critical thinking skills so that they could become competent, independent, critical-thinking nurse practitioners. Nursing practice requires a high level of cognitive development and independent thinking. Students who are skilled in problem solving and have learnt to use problem-solving scientifically will become safe practitioners. Problem solving teaches students to solve individual identified problems, and requires the ability to make associations (Mashaba \& Brink 1994:273).

The importance of informed and skilled nurses who can think critically is undisputed. By nursing practice standards, knowledge should be implemented and applied to ensure safe and effective nursing care (Mashaba \& Brink 1994:44).

Scientific nursing only realises when students correlate nursing practice with nursing theory (Kathol, Geiger \& Hartig 1998:31-34). Students must be able to scientifically motivate their actions in nursing practice, and this ability requires analytical critical-thinking skills. Logical critical thinking and a cognitive learning experience require that students actively process information and transform it into new knowledge (Hinchliff 1999:19).

Time spent on nursing education in the clinical field is essential because this is where students experience the science of nursing in real-life situations under the supervision of clinical facilitators. The quality of learning experiences in this context can be influenced by the methods and the educational approaches used. Accompaniment methods currently in use in the clinical field do not seem to enhance and develop the critical thinking skills of students.

Furthermore, no concrete programmes are available to guide facilitators regarding the use of strategies that facilitate critical thinking during the clinical accompaniment of students. The dynamics underlying the facilitation of clinical decision-making processes can thus be described as problematic. The apparent inability of students to use critical thinking skills and unsatisfactory performances in this regard can be due to ineffective accompaniment in clinical practice by clinical facilitators.

The question now arises: Does student accompaniment by clinical facilitators lead to the development of critical thinking skills in students?

\section{Research objectives}

The objectives of this study were:

- To identify methods of accompaniment that were described in literature as enhancing the development of critical thinking skills in students;

- $\quad$ To determine the methods of student accompaniment used by clinical facilitators in clinical practice (a descriptive analysis);

- $\quad$ To determine if the methods of clinical accompaniment used by facilitators correlated with those identified in the literature as facilitating the development of critical thinking;

- To identify and describe possible shortcomings and loopholes in clinical accompaniment;

- $\quad$ To make recommendations regarding shortcomings in clinical accompaniment, where applicable, and

- $\quad$ To establish the understanding and application of certain concepts related to $\mathrm{OBE}$

\section{Definitions of key concepts Clinical facilitator}

The clinical facilitator provides professional guidance and academic leadership to students, mainly in the clinical field. The role of facilitator is to provide specialist experience during the integration of theory and practice (Mellish \& Brink 1990:220).

\section{Student or student nurse}

A student or a student nurse is a person who follows a programme of education and training that was approved by the South African Nursing Council (SANC). Regulation 425, 1982, Article 15(3), and leads to the acquirement of a qualification that gives the keeper thereof the right to register as a nurse (general, psychiatric, community) and a midwife.

\section{Clinical accompaniment}

The clinical accompaniment of a student is the process whereby the student is guided and accompanied by the clinical facilitator in order to become a professional and independent nurse practitioner (Klopper 1999: 110).

\section{Scientific nursing}

Scientific nursing incorporates the safe and skilful care given to patients according to preset standards. It includes the attainment of skills such as critical thinking and analytical reasoning and is based upon scientific knowledge. Scientific nursing is regulated by the Scope of Practice regulation of the SANC (1984).

\section{Facilitation}

For the purposes of this study, facilitation can be described as the accompaniment of students in the clinical field with the purpose of enabling them to achieve high levels of cognitive thinking, reasoning, problem stating and problem solving. Students are encouraged to use information, knowledge, technologies, facts, and skills to ensure correct interpretation and management of health processes. It is a goal-driven, dynamic process of critical reflection in which participants work together in an atmosphere of learning and mutual respect (Burrows 1997:401).

\section{Critical thinking}

Critical thinking is the ability to solve problems by using high cognitive thinking processes whereby information is implemented in a creative, logical, analytical and scientific manner. It is thus an ongoing, creative, logical and analytical process (Hansten \& Washburn 1999: 39).

\section{Research design and method}

\section{Research design}

A quantitative study was conducted. The researcl design can be described as descriptive, explorative, and contextual, reflecting the methods of clinical accompaniment used by facilitators. The goal of descriptive studies is to observe, to describe and to document certain aspects of a situation (Polit \& Hungler 1997:168)

\section{Research Method}

The following phases characterised the research method:

12 
through an in-depth literature study.

- $\quad$ Methods of accompaniment facilitating the development of critical thinking were identified during the literature study.

A deductive strategy was

followed, and a structured questionnaire was compiled and implemented. The questionnaire was used as a guideline throughout the interpretation and analysis of data.

\section{Population and sampling}

The population consisted of registered nurses involved in the clinical accompaniment of all categories of student nurses in educational and health institutions in Gauteng.

Purposive sampling was used. Certain participants in one geographical area were consciously selected to ensure that participants of a specific field of experience would be included. The participants were believed to have specialised knowledge and insight into certain experiences (De Vos 1998:190).

Regarding inclusion in the sample population, the following criteria were stipulated:

\section{- $\quad$ Registration as a professional nurse with the SANC; \\ - Working in Pretoria at a health or educational facility where training in nursing is provided; Accepting the responsibility for accompanying students in clinical practice or a speciality field; \\ - $\quad$ Nursing staff subcategories such as enrolled nurses were excluded from the study.}

\section{Research setting}

Participants' duties included lecturing nursing students and included the clinical accompaniment of these students in clinical practise. Not one of the participants was at the time of the study part of the clinical field. Working in the clinical setting was not required of them. Participants included in this study were responsible for accompaniment in a variety of clinical settings. Specific clinical areas were not the focus in this study.

\section{Research instrument}

Based on the literature review, closed and open-ended questions were formulated. The validity of a measuring instrument can be described as the ability of the instrument to correctly measure specific concepts (De Vos 1998:83).

In this study, the validity of the content of the questionnaire (that was based on the literature review) was judged by seven academics. They were specialists in fields relevant to that surveyed by the researcher and were well informed about the topic.

In this study, applying a parallel form of reliability testing ensured reliability. Parallel test forms are interchangeable versions that are compiled to measure the same construct equally well by means of different contents (Huysamen 1994:120). In the questionnaire under discussion, reliability testing realised through different questions testing the same concept. This parallel method of reliability testing increased the value of the findings. If the trustworthiness of a response was questioned, a parallel form of measurement could be conducted to present the researcher with a comparative result. That was done in this study. Data results of different questions measuring the same concept were compared.

\section{Data collection}

One hundred and ten (110) questionnaires were handed out and collected personally, ensuring total anonymity and confidential handling of completed questionnaires. The response rate (questionnaires completed and returned) was fifty-nine per cent $58 \%(\mathrm{~N}=64)$.

The total amount of questionnaires that could be used was $53 \%(\mathrm{~N}=59)$. In an attempt to increase response rate the questionnaires were personally handed out and recollected by the researcher. The response rate of one institution however had remarkable effect as only ten questionnaires were received back. Fifty were handed out. Possible reasons for this poor response could have been busy schedules during examination as this was the only available time before the holidays.

\section{Data analysis}

The SAS computer software package was employed to obtain both descriptive and statistical summarisations of data. and findings were depicted in tables and graphs and discussed accordingly.

\section{Literature study}

The importance of the development of critical thinking in nursing education is discussed in detail throughout the literature. The researcher identified the lack of practical guidelines regarding clinical accompaniment as an impediment to significant accompaniment (Oliffe 2000:1) The importance of the development of critical thinking in the education of nursing students must be evident in nursing theory and, especially, nursing practice (Fowler 1998: 183).

The researcher realised through the literature study that students would not have the ability to use scientific reasoning to ensure correlation of theory with practice if critical thinking were not developed (Celia \& Gorden 2001:13). Implementing the correct methods of accompaniment during clinical accompaniment of nursing students and using practical examples can develop critical thinking. Critical thinking will develop as students broaden their clinical field of experience. Scientific nursing will result. In literature, various methods of accompaniment, which can be implemented to facilitate critical thinking, are discussed (Hart 2000:31).

Although clinical facilitators seem to be doing their utmost, it is proved that the development of critical thinking in the clinical field does not realise as desired (Greenwood 2000:428). To think critically means to think further than the obvious and to make enlightened and goalorientated decisions (Fowler 1998:183). The dynamic health systems of today require skilled professionals that have the ability to use critical thinking skills to make accurate clinical decisions (Videbeck 1997:23). Today's neverending sources of knowledge and everchanging technologies require professionals that can think critically. The professional nurse needs a wide field of knowledge to use resources effectively, coordinate actions and evaluate outcomes. Critical thinking skills enable nurses to deliver quality healthcare in times of scarce resources and finances. and growing responsibilities (Jacobs. Ott, Sullivan, Ulrich \& Short 1997: 19).

Inexperienced clinical facilitators can negatively affect the implementation of accompaniment methods. Inefficient accompaniment of students can further lead to ineffective learning experiences. Facilitators' scientific knowledge and 
clinical and didactic skills form part of the challenging requirements of nursing education (O'Neill \& Dluhy 1997:6). Facilitators should be able to apply their knowledge and skills effectively. This must realise in the class situation as well as in the clinical field where scientific knowledge is applied through the art of nursing (Grealish 2000:231).

\section{Findings: Socio- demographic aspects \\ Qualifications}

Thirty-two per cent 46\%; ( $n=27)$ of the respondents did not have a qualification in nursing education. The following demographic information is depicted:

$19 \% ;(n=11)$ obtained a diploma in Nursing Education,

$27 \%$; $(n=16)$ a Baccalaureus in Nursing Education,

$7 \%$; $(n=4)$ a Masters Degree in Nursing Education,

$2 \% ;(n=1)$ a Doctoral Degree in Nursing Education.

After obtaining clinical qualifications, the mastering of didactic skills was emphasised as essential (Sergiovanni 1995:212).

\section{Clinical experience}

The clinical experience of respondents was considered important and relevant, because nursing students form perceptions of their professional and nursing responsibilities and roles by observing the skills of facilitators at the bedside of a patient. Therefore, the importance of a clinically skilled facilitator cannot be stressed enough (FothergillBourbonnais \& Higuchi 1995:37).

Forty-nine per cent $(49 \% ; n=29)$ of the respondents had five to ten years of clinical experience. They may have been able to convey valuable information acquired through extensive clinical experience to the benefit of the students. However, clinical experience must be recent, as healthcare methods and technologies change continuously. Commitment to lifelong learning will ensure that clinical facilitators stay abreast of new methods and technologies. Optimally skilled, they will be able to function as role models (Benor \& Leviy 1997:206). From own experience, the researcher can conclude that clinical skills can be optimally achieved only if a person is working in the clinical field. If clinical facilitators were educated and trained before outcomes-based edu- cation was introduced in 1999, they would not be up to date with the newest tendencies in education and training, and knowledge would be transferred in the old manner. The facilitating process may not realise and students' thinking abilities may not be developed optimally. However, if facilitators were committed to lifelong learning, they would have the advantage of combining learning opportunities with specialist experience in an OBE approach. Facilitation techniques could be integrated into the teaching process, and students' critical thinking skills could be developed. In this scenario, optimal clinical accompaniment will occur.

The following conclusion is made: If didactic knowledge and clinical skills are integrated, and are recent, the facilitator will function as a clinical specialist. The clinical facilitator becomes a role model, and the clinical experience of the facilitator will lead to the creation of improved clinical learning opportunities and theory-practice correlation will be ensured.

\section{Number of years experience in clinical accompaniment}

Forty-two per cent ( $42 \% ; n=25)$ of the respondents had done clinical accompaniment for a period of ten years, and fifty-five per cent $(55 \% ; n=33)$ did it for eight years. These findings imply that a total of ninety-seven per cent $(97 \%$; $\mathrm{n}=58$ ) obtained their nursing qualifications before OBE was implemented, because they have been doing clinical accompaniment for more than 5 years. Since 1999, changes in Higher Education have resulted in changes in the approach towards the education and training of student nurses. In the new approach, facilitating the development of thinking processes in students is preferred above the didactic transference of knowledge.

If clinical facilitators did not stay abreast of the newest skills and educational strategies in $\mathrm{OBE}$, the quality of accompaniment would not deliver students of high quality. In today's complex and changing healthcare systems, a wide variety of stimulating educational strategies lays the basis for quality assurance and adherence to the challenges of the 21 st century (Williams 2001:135).

\section{Findings: Concepts investigated}

After conducting the literature review, the researcher identified important concepts in the field of clinical accompaniment. Respondents' perceptions regarding these concepts were tested through the questionnaire, and the findings are discussed under the following headings:

\section{Critical thinking}

In this study, the characteristics of a person with critical thinking abilities, as identified by the respondents, did not correspond to those found in the literature. The methods of accompaniment used by the respondents in clinical practice did however match those found in the literature. However, the successful application of these methods depends upon the innovation and creativity of clinical facilitators. Therefore, the application of these methods requires clinical facilitators who have insight into the concepts 'critical thinking' and 'facilitation'. It also requires competent facilitators with facilitating skills and critical thinking abilities.

If the importance of skills such as analytical thinking and scientific reasoning is negated, they will not be regarded as priorities, and not be pursued in the learning situation. Clinical facilitators then will attend more to role learning and clinical skills, as psychomotor activities only. The importance of the development of thinking processes that enable students to apply knowledge scientifically will be lost. Such a situation will prevent students from developing the ability to analytically motivate and debate their actions. Theory-practice correlation will not occur. Respondents in this study who have indicated clinical skills of far more importance than theory-practice correlation confirmed this conclusion. Theory application in the clinical field is essential as it enables the student to understand disease processes and their clinical manifestations. Clinical practice must be based on scientific knowledge.

Students' abilities to use analytical thinking will be enhanced if they receive the necessary guidance in cognitive development. The quality of scientific discussions of identified problems will improve, and significant theory-practice correlation will become evident. The nursing of patients with complex health problems requires registered nurses that have critical thinking skills as well as a 


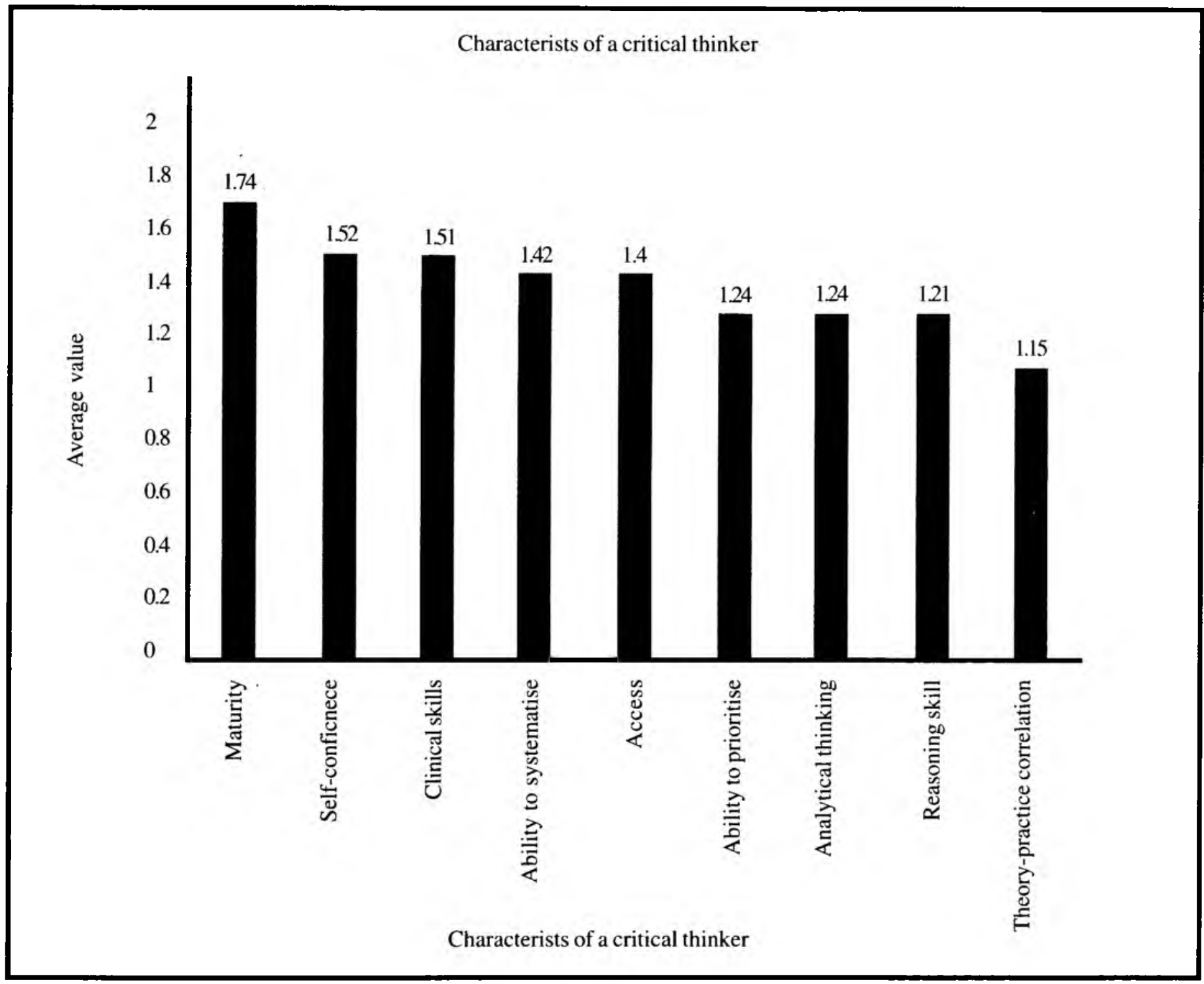

strong scientific knowledge base.

Critical thinking equips students with the necessary skills to process and analyse information, solve clinical problems and implement applicable actions (Oermann, Truesdell \& Ziolkowski 2000:155). The development of critical thinking skills in students is the responsibility of the clinical facilitator. The ultimate goal is a student who can apply theory in a meaningful and scientifically justifiable manner.

While developing analytical thinking processes, reasoning abilities and clinical skills, students learn to prioritise, which again enhances their ability to systematise in practice. Theory-practice correlation then realises. Students develop self-confidence as competent clinical practitioners, and consequently accept facilitators' positive input. Students mature in their relationship with preceptors that they regard as role models. Mutual trust and understanding develop. Students are led to professional as well as cognitive maturity. The respondents were asked which characteristics they regarded as important in a student with critical thinking skills. The respondents had to list the characteristics according to importance. Their responses are demonstrated by means of a column graph in Figure 1.

Not without some degree of concern, the researcher inferred from Figure 1 that respondents regarded the following most important characteristics of a critical thinker of lesser importance:

- Analytical thinking skills;

- $\quad$ Scientific reasoning ability;

- The ability to correlate theory with practice; and

- The ability to prioritise.
This leads to the conclusion that the development of critical thinking skills in students does not realize in practice. The reason being that clinical facilitators do not regard them as important. Therefore the researcher has great uncertainty that the clinical facilitators will have the ability to facilitate critical thinking skills effectively.

\section{Facilitation}

Facilitation means that students are guided to identify health problems and find solutions themselves. The facilitation process is complex, and is described as a big challenge to current dynamic educational systems (Oliffe 2000:1).

Outcomes-based learning leads to the development of practical skills, learning competencies, thinking processes, social skills and values. Outcomes-based learning also determines attitudes 
towards contents and their application. It enables the student to integrate all aspects mentioned above, and to achieve various other outcomes in new situations, contexts and arenas (Olivier 2000:59). It becomes clear that $\mathrm{OBE}$ in itself requires the facilitation process because student driven learning takes place when the student is guided in the learning process.

Referring to the definition of OBE, OBE methods will facilitate critical thinking, provided the facilitation process is implemented correctly. Furthermore, the importance of knowledge about OBE becomes evident. Clinical facilitators should have knowledge of and insight into new methods of facilitation and accompaniment in order to allow the realization of meaningful clinical experiences.

The respondents were asked to indicate the methods they would use to facilitate a learning experience. The options provided to them as well as their responses can be seen in Figure 2.

As displayed in Figure 2, 60\% $(n=35)$ of respondents indicated that they would make the student aware of the problem giving guidance regarding knowledge application and problem solving. Thirtyseven percent $(n=22)$ of respondents indicated that they would prefer to let the student work through the data, and identify problems themselves while the facilitator is giving guidance. Only $3 \%$ $(n=2)$ of the respondents indicated that they would present a lecture to enhance comprehension. No respondent indicated that $s /$ he would state the problem and give it as an assignment to the students to complete. These results indicate that respondents' insight regarding the process of facilitation was not sufficient. Students must be able to identify problems independently and must be guided to do just this in order to be safe clinical practitioners.

A possible explanation for the responses in Figure 2 may be that many clinical facilitators did their training before OBE was introduced. To many, student-

Identification of facilitation techniques

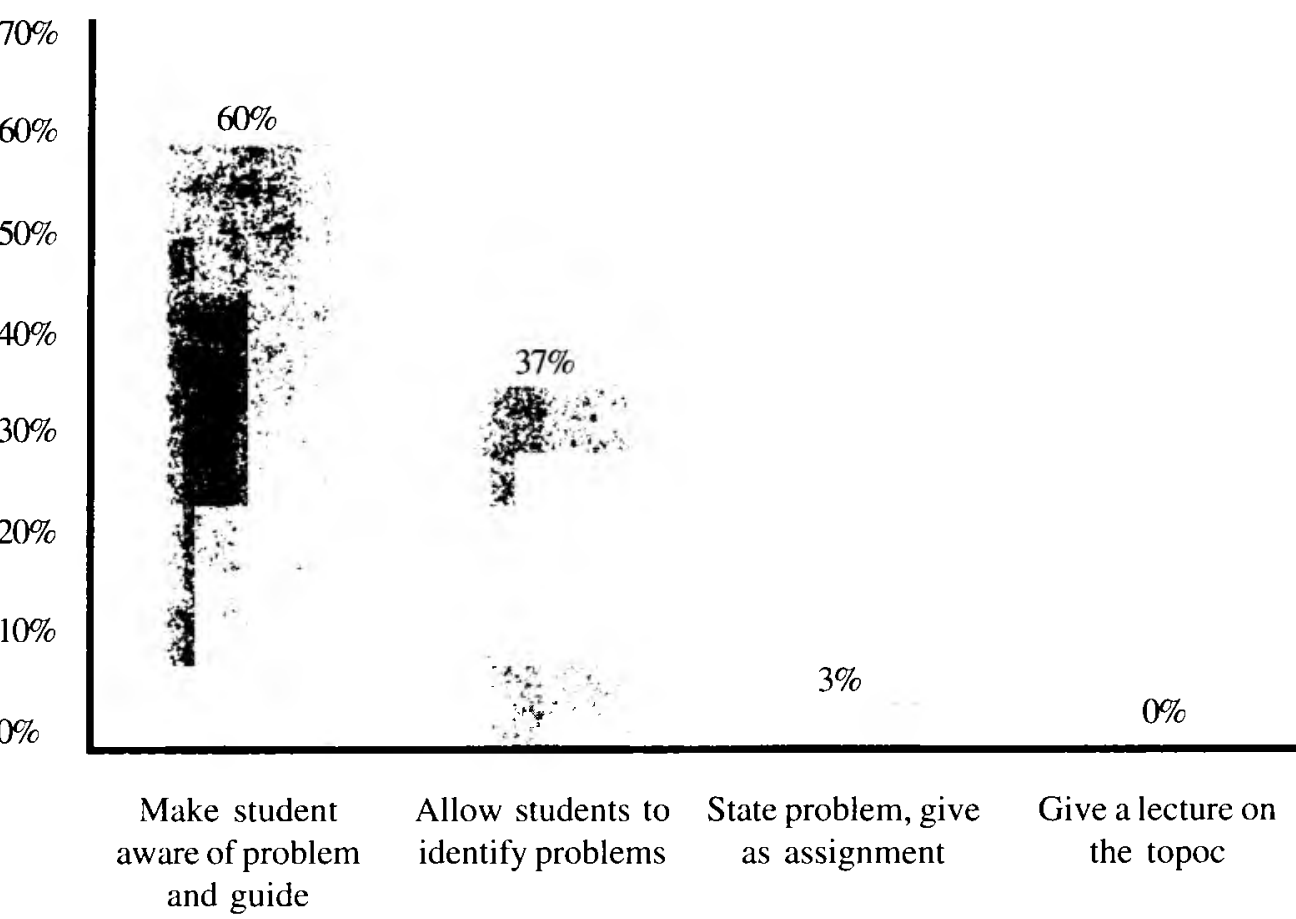

driven learning is still an unknown concept, and students are expected to memorize and reproduce facts rather than apply knowledge with insight. This is greatly problematic as it is clear that critical thinking is not developed because students do have factual knowledge but will they be able to apply it?

In the literature, the term 'facilitation' was pointed out as a difficult and abstract concept. and described as not easily interpretable. Facilitation and its success depend upon the understanding facilitators have of their new educational role, one of giving guidance to students rather than attempting to transfer knowledge. Facilitation is being emphasized as an important aspect of OBE, and facilitators have to show a thorough understanding of this concept if they want to act as facilitators (Burrows 1997:396).

\section{Methods of clinical accompaniment}

The survey confirmed that clinical facilitators were generally knowledgeable about the various training methods identified in the literature review as methods that facilitated critical thinking. Clinical facilitators were well informed regarding research tendencies, training methods and strategies. It can be inferred that clinical facilitators are adult learners who believe in continuous development and follow a philosophy of lifelong learning. It can however be argued that if, as previously discussed, clinical facilitators don't have insight in concepts critical thinking and facilitation it will not be implemented correctly.

The following aspects were identified as important during the literature review and analysis of the research findings:

- Reflection as part of clinical accompaniment is described as a method that is commonly used in various fields of healthcare training (in the classroom and in nursing practice) (Hyrkas, Tarkka \& Paunonen-Ilmonen 2001:504).

- Reflection is recommended as a method to overcome the problem of theory-practice correlation and to develop practice-based nursing knowledge (Smith 1998:891).

- Clinical learning activities such as the presentation of patient studies form an important aspect of critical thinking skill development.

- Respondents identified the presentation of patient studies 
as the most important strategy for developing critical thinking skills. During patient studies, disease processes are analysed and their clinical manifestations in practice are discovered.

During the presentation of these studies, students are guided to make use of pathophysiology and theory. Scientific actions are planned after an assessment of the patient has been done. The student learns to think analytically, and to sift and prioritise data that were obtained from medical reports, the findings of the physical examination and the patient's medical history. Clinical and cognitive skills and theoretical knowledge develop during patient presentations. Holistic nursing occurs, and the student develops as a professional practitioner by being exposed to members of the multidisciplinary team.

- $\quad$ Legal and ethical aspects are impressed upon students. As registered nurses, students learn to co-ordinate their role as advocate for both the patient and the healthcare system. Respondents and the literature identified group work, group discussions and collective learning sessions as important accompaniment or learning strategies that would stimulate critical thinking par excellence.

With reference to the facilitation of critical thinking, the lecturing method was given the lowest priority by respondents. However, lectures can be implemented in combination with group discussions, think tanks and collective learning sessions as an equivalent and innovative strategy. Lectures are seldom used during clinical accompaniment of students, and are therefore underrated.

As mentioned earlier, methods identified by clinical facilitators with regard to the development of critical thinking skills were in accordance with those identified in the literature. However, the researcher was not convinced that the correct facilitation techniques were used during the application of identified methods. It also became evident that the development of critical thinking skills and thinking patterns did not enjoy first priority during the clinical accompaniment of students. In this study, both these issues could be described as obvious deficiencies.

\section{Evaluation of the study Positive aspects}

The research is relevant as critical thinking is a requirement of scientific nursing. Furthermore, the research is important because the development of critical thinking enables the learner to develop into and function as a competent nursing practitioner. Accompaniment methods indicated by facilitators were in accordance with those presented in the literature review as methods that facilitate the development of critical thinking. It seemed, however, that these methods were not always applied correctly.

The respondents will receive feedback regarding the research. This is a positive aspect, as feedback may guide their attitudes towards clinical accompaniment and impress upon them the necessity of facilitating critical thinking.

\section{Limitations of the research}

Models of accompaniment of students in clinical practice are not available, and therefore students performing inadequately cannot be remedied (Spier, Matthews, Jack, Lever, McHaffie \& Tate 2000:38). Various factors that may contribute to ineffective accompaniment of students by clinical facilitators are a big number of students, negative attitudes regarding hospital work, remote clinical areas, and the loss of skills or lack of confidence to move into practice (Mashaba \& Brink 1994:47-50). The scope and extent of the clinical responsibilities of the nurse educator are emphasized by Mashaba and Brink (1994:50-52).

Although a void exists concerning concrete models that can guide the clinical accompaniment of students. literature describes various techniques that can be used to facilitate the development of critical thinking in students. The researcher had to use the literature study as the basis for the compilation of the questionnaire.

\section{Recommendations}

One of the aims of this study was to make recommendations regarding further research in nursing education. By implication the conclusion drawn by the researcher during the literature study and data analysis was that clinical facilitators should be able to think critically themselves if they want to facilitate critical thinking in students. The clinical facilitator's field of knowledge should be extensive to guide students by means of science-based reasoning through the processes of developing correct thinking patterns and mental attitudes. Successful learning activities depend on effective problem stating, and effective problem stating is determined by critical thinking. Therefore, the facilitator's ability to think critically should be emphasized once again. Knowledge and its integration form the basis of critical thinking.

Students become involved in study contents when they are guided to develop cognitive thinking patterns. The student considers the study content, it becomes integrated knowledge, and content can now be used meaningfully. Facilitating critical thinking implies enhancing understanding and insight into performance. It also implies accepting responsibility for actions that are based on scientific and factual knowledge.

A further important conclusion was that the concepts 'facilitation' and 'critical thinking" were not understood correctly, and that both would not be treated or applied correctly.

The researcher therefore recommended that a training course be offered that could fill this void. Such a course could take the format of a refresher course for clinical facilitators who were trained before OBE was instituted. The course can be propagated for attendance by any person who was responsible for the clinical accompaniment of students and who would like to rectify own deficiencies in this regard.

Clinical facilitators, who accompany students in clinical practice, experience a lack of concrete guidelines that can assist them in the development of students abilities to think critically (Chabeli 1998:39). The researcher therefore recommended that concrete guidelines for student accompaniment in clinical practice be drawn up. This study can serve as a basis for the development of a practical guide or model that presents specific methods of clinical accompaniment of students in clinical practice. 
Moreover, the model should include specific guidelines that could be implemented to enhance the development of critical thinking skills.

\section{Conclusion}

It was evident from the literature review that the ability to think critically could be developed through purposeful accompaniment (Jacobs, Ott, Sullivan, Ulrich \& Short 1997:19-22). Guiding students through the development process of critical thinking is an art that can only be mastered by persons who are competent in both theory and practice. Nurse educators should become involved in programs that prepare students for the present and the future, and equip them for service in a dynamic profession (Reilly \& Oermann 1992:451).

In conclusion, the following aspects are emphasized:

- $\quad$ Nurse educators should be critical thinkers themselves if they want to develop this characteristic in their students. Critical thinking is a developmental process that requires thorough planning of learning activities to ensure the correct application of knowledge. It should be included in the curriculum from the first study year onwards, and specific planning should be done to ensure the development and evaluation of critical thinking.

- $\quad$ Scientific knowledge provides the basis for the development of critical thinking.

- $\quad$ The success of learning activities depends on effective problem stating and evaluation.

Facilitation implies knowledge of the concept, and is a purposeful, dynamic process in which the student is guided to form thinking patterns. This, by implication, means that nurse educators should be lifelong learners who stay abreast of the newest tendencies in nursing education and training (inter alias by attending courses).

Demands for models of clinical accompaniment and refresher courses in terms of outcomesbased education should be addressed by further research and additional courses. These are the challenges and responsibilities put to every nurse educator and researcher today.

The development of the critical thinking skill is being emphasized as a requirement for the safe, competent, capable practitioner, and is essential for true independency. Critical thinking is also required during problem-solving, analytical reasoning, data analysis and the drawing of conclusions (Chabeli 1998:39).

Various authors stress the responsibility of clinical facilitators regarding the development of critical thinking through the usage of specific training methods. The concept 'critical thinking' should be defined, and the methods of accompaniment that will ensure its realization should be clearly described. By facilitating critical thinking in students from their first study year onward and by evaluating its development continuously, students will achieve competent levels of critical thinking skills (Abegglen \& O'Neill Conger 1997:452). The only remedy for the gaps in clinical accompaniment is the introduction of useful practical programs that are applicable to all levels of student accompaniment.

\section{List of references}

\section{ABEGGLEN, J \& O'NEILL CONGER,} C 1997: Critical thinking in nursing: Classroom tactics that work. Journal of Nursing Education. 36(10): 452 - 458.

BENOR, DE \& LEVIYOF, I 1997: The development of the student's perceptions of effective teaching: The ideal, best and poorest clinical teacher in nursing. Journal of Nursing Education. 36(5): 206.

BURROWS, DE 1997: Facilitation: A concept analysis. Journal of Advanced Nursing. 25: 396 - 404.

CELIA, LM \& GORDEN, PR 2001: Using problem based learning to promote critical thinking in an orientation program for novice nurses. Journal for nurses in staff development. 17(1): 12-19.

CHABELI, M 1998: Professional nurses as reflective clinical learning facilitators. Curationis. 21(2): 39 - 44.
DE VOS, AS 1998: Research at grass roots: A primer for the caring professions. Pretoria: Van Schaik.

FOTHERGILL-BOURBONNAIS, F \& HIGUCHI, KS 1995: Selecting clinical learning experiences: An analysis of the factors involved. Journal of Nursing Education. 34(1): 37.

FOWLER, LP 1998: Improving critical thinking in nursing practice. Journal for Nurses in Staff Development. 14(4): 183 187.

GREALISH, L 2000: The skills of coach are an essential element in clinical learning. Journal of Nursing Education. 39(5): 231-233.

GREENWOOD, J 2000: Critical thinking and nursing scripts: The case for the development of both. Journal of Advanced Nursing. 31(2): 428-436.

HANSTEN, RI \& WASHBURN, MJ 1999: Individual and organizational accountability for development in critical thinking. Journal of Nurse Administration. 10(11): 39-45.

HART, LB 2000: Integrating technology and traditional teaching methods to stimulate different cognitive styles in a critical care course. Journal for nurses in staff development. 16(1):31.

HINCHLIFF, $S$ 1999: The practitioner as teacher. $2^{\text {nd }}$ Editon. New york: Bailliére Tindall.

HUYSAMEN, GK 1994: Methodology for the social and behavioural sciences. Pretoria: Sigma Press.

HYRKAS, K; TARKKA, M \& PAUNONEN-ILMONEN, M 2001: Reflection in clinical teaching, Journal of Advanced Nursing, 33(4). Available online: Ovid_online@ovid.com. [Accessed: 29 October 2001.]

JACOBS, PM; OTT, B; SULLIVAN, B; ULRICH, Y \& SHORT, L 1997: An approach to defining and operationalizing critical thinking. Journal of Nursing Education, 36(1): 19-22.

KATHOL,DD; GEIGER, ML \&HARTIG, JL 1998: Clinical correctional map: A tool for linking theory and practice. Nurse Educator. 23(4): 31-34. 
KLOPPER, H 1999: Nursing education: A reflection. West Cape: Amabhuku Publications.

MASHABA, TG \& BRINK, HI 1994: Nursing education: An international perspective. Cape: Juta \& Co.

MELLISH, JM \& BRINK, HI 1990: Teaching the practice of nursing: A text in nursing didactics. $3^{\text {rd }}$ Edition, Butterworths: Durban.

OERMANN, M; TRUESDELL, S \& ZIOLKOWSKI, L 2000: Strategy to assess, develop and evaluate critical thinking. The Journal of Continuing Education in Nursing. 31(4): $155-160$.

OLIFFE, J 2000: Facilitation in problembased learning, Australian Electronic Journal of Nursing Education, 5(2). Available online: www.scu.edu.au/ schools/nhcp/aejne/archive/vol2-1/ mc21.htm. [Accessed: 24 August 2000.]

OLIVIER, C 2000: Let's educate, train and learn outcomes-based: A 3D experience in creativity. Pretoria: Benedict.

O'NEILL, E \& DLUHY, N 1997: A longitudinal framework for fostering critical thinking and diagnostic reasoning. Journal of advanced nursing. 26(4): 6 .

REILLY, DE \& OERMANN, MH 1992: Clinical teaching in nursing education. $2^{\text {nd }}$ Edition. NLN: New York.

SERGIOVANNI, TJ 1995: The principalship - A reflective practice perspective. $3^{\text {nl }}$ Edition. Texas: Allyn and Bacon.

\section{SPIER, BE; MATTHEWS, JT; JACK, L;}

LEVER, J; MCHAFFIE, EJ \& TATE, J 2000: Impaired student performance in the clinical setting: A constructive approach. Nurse Educator. 25(1): 38-42.

SOUTH AFRICA 1984: Regulations relating to the scope of practice of persons who are registered or enrolled under the nursing act, 1978. Regulation R. 2598, in terms of the nursing act, 1978 (Act no. 50, 1978 as amended). Pretoria: Government Printer.

SOUTH AFRICA 1984: Regulations relating to the scope of practice of persons who are registered or enrolled under the nursing act, 1978. Regulation R. 425, in terms of the nursing act, 1978 (Act no. 50, 1978 as amended). Pretoria: Government Printer.

VIDEBECK, SL 1997: Critical thinking: A model. Journal of Nursing Education. $36(1): 23-28$.

WILLIAMS, J 200: The clinical notebook: Using student portfolios to enhance clinical teaching. Journal of Nursing Education. 40(3): 135-136. 